\title{
Penilaian Kualitas Air Tanah di Kecamatan Jenu Kabupaten Tuban Berdasarkan Indeks Kualitas Air Irigasi
}

\author{
Hari Siswoyo*, Joko Kurniawan \\ Jurusan Teknik Pengairan, Fakultas Teknik, Universitas Brawijaya \\ Jl. M.T. Haryono 167 Malang, Jawa Timur \\ *Correspondence email: hari_siswoyo@ub.ac.id
}

\begin{abstract}
Abstrak. Air tanah yang digunakan untuk irigasi harus memiliki kualitas yang sesuai dengan peruntukkannya. Tujuan dilakukannya studi ini adalah untuk menilai kelayakan kualitas air tanah yang digunakan sebagai sumber air irigasi. Studi ini dilakukan pada lahan pertanian di daerah yang dekat dengan pantai dan berpotensi terintrusi air laut. Lokasi studi ini adalah lahan irigasi air tanah di daerah oncoran sumur produksi SDTB 063, SDTB 064, dan SDTB 342 yang berada di Kecamatan Jenu Kabupaten Tuban Provinsi Jawa Timur. Penilaian kualitas air tanah dilakukan dengan menggunakan model IQWI. Berdasarkan nilai IWQI yang diperoleh dapat ditunjukkan bahwa kualitas air tanah dari sumur produksi SDTB 064 dan SDTB 342 miliki batasan penggunaan air rendah, sedangkan kualitas air tanah dari sumur produksi SDJB 603 memiliki batasan penggunaan air sedang. Kualitas air tanah dengan batasan penggunaan air rendah dapat digunakan sebagai air irigasi pada tanah dengan permeabilitas sedang dengan anjuran dilakukan pencucian garam. Kualitas air tanah dengan batasan penggunaan air sedang dapat digunakan sebagai air irigasi pada tanah dengan permeabilitas sedang hingga tinggi dengan anjuran dilakukan pencucian garam. Petani di wilayah studi disarankan untuk dapat membudidayakan berbagai alternatif tanaman bernilai ekonomis tinggi yang sesuai dengan kualitas air tanah yang digunakan sebagai sumber air irigasi sebagaimana yang tertuang dalam studi ini, dengan tetap melakukan penyesuaian terhadap kondisi lahan pertanian dan kondisi iklim.
\end{abstract}

Kata kunci: air tanah; irigasi; kualitas air; tanah; tanaman pertanian.

Abstract. The groundwater used for irrigation must have the quality according to its designation. The objective of this study was to assess the appropriateness of groundwater quality used as a source of irrigation water. This study was conducted on agricultural land in an area close to the coast and potentially intruded by sea water. The location of this study was groundwater irrigation land in the irrigation area of production wells SDTB 063, SDTB 064, and SDTB 342 located in Jenu District, Tuban Regency, East Java Province. Groundwater quality assessment was carried out using the IQWI model. Based on the IWQI value obtained, it can be shown that the groundwater quality from SDTB 064 and SDTB 342 production wells has low water usage restrictions, while the groundwater quality from SDJB 603 production well has moderate water usage restrictions. Groundwater quality with low water usage restrictions can be used as irrigation water on soils with moderate permeability with a recommendation to wash the salt. Groundwater quality with moderate water usage restrictions can be used as irrigation water on soils with moderate to high permeability with a recommendation to wash the salt. Farmers in the study area are recommended to be able to cultivate various alternative of high economic value crops that are suitable with the groundwater quality used as a source of irrigation water as stated in this study, while still making adjustments to agricultural land conditions and climatic conditions.

Keywords: agricultural crops; groundwater; irrigation; soil; water quality

\section{PENDAHULUAN}

Air tanah dapat didefinisikan sebagai air yang terdapat dalam lapisan tanah atau batuan di bawah permukaan tanah (Undang-undang Republik Indonesia Nomor 17 tahun 2019 tentang Sumber Daya Air). Salah satu peran penting air tanah dalam sektor pertanian adalah sebagai sumber air irigasi untuk lahan pertanian pada saat musim kemarau, dimana kebutuhan air irigasi tidak dapat dipenuhi oleh air permukaan. Pemanfaatan sumber daya air tanah untuk irigasi dilakukan melalui pembangunan sistem irigasi air tanah (irigasi pompa). Upaya tersebut merupakan salah satu alternatif untuk meningkatkan taraf hidup petani. Keberadaan sumur pompa tersebut dapat memberikan dampak terhadap penambahan pola dan intensitas tanam pada lahan pertanian, sehingga memungkinkan kegiatan petani berlangsung sepanjang tahun (Tika, 1990).
Kecamatan Jenu Kabupaten Tuban merupakan suatu daerah yang berada di dekat pantai dan secara langsung berbatasan dengan Laut Jawa. Luas wilayah kecamatan tersebut 8.161 ha yang didominasi oleh penggunaan lahan sawah $(1.908,23$ ha) dan ladang (4.094,2 ha), dengan berbagai jenis komoditas pertanian yang telah diusahakan oleh petani setempat (Badan Pusat Statistik Kabupaten Tuban, 2019 ${ }^{\mathrm{b}}$ ). Terkait dengan pemanfaatan air tanah, di wilayah Kecamatan Jenu terdapat 5 sumur pompa untuk irigasi (sumur produksi) dimana 4 diantaranya dalam kondisi baik (3 sumur produksi berfungsi untuk irigasi dan 1 sumur produksi beralih fungsi untuk air minum) (sda.pi.go.id/bbwsbengawansolo/siatab, diakses 6 Juli 2019). Berdasarkan kondisi tersebut di atas, dapat ditunjukkan bahwa wilayah Kecamatan Jenu merupakan salah satu representasi dari kawasan lahan pertanian 
pada daerah di dekat pantai dengan sumber air irigasi dari air tanah yang berpotensi terintrusi air laut atau memiliki potensi bahaya salinitas.

Untuk dapat digunakan sebagai air irigasi, air tanah harus memenuhi syarat kualitas air yang sesuai dengan peruntukannya. Hal ini dikarenakan kualitas air tanah tersebut dapat memberikan pengaruh bagi lahan pertanian (tanah dan tanaman) yang diari (Siswoyo et al., 2018). Penilaian kualitas air tanah untuk irigasi dapat dilakukan dengan menggunakan model indek kualitas air irigasi (model IWQI) berdasarkan 5 parameter dan perhitungan matematika (Meireles et al., 2010). Model IWQI tersebut telah digunakan secara meluas dalam sejumlah penelitian untuk menilai kesesuaian dan kelayakan kualitas air tanah untuk air irigasi (Khalaf \& Hassan, 2013; Al-Mussawi, 2014; Omran et al., 2014; Siswoyo et al., 2016; Abdulhady et al., 2018; Siswoyo et al., 2020 ${ }^{\text {b; }}$ Siswoyo et al., 2020 a).

Model IWQI sebagai salah satu metode untuk penilaian kualitas air tanah yang digunakan sebagai sumber air irigasi telah dikembangkan penggunaannya untuk menentukan jenis tanaman pertanian yang dapat diusahakan pada lahan irigasi air tanah pada daerah yang didominasi oleh formasi geologi endapan lahar dan aluvium, serta bukan merupakan daerah pantai ataupun daerah berkapur (Siswoyo et al., 2016). Penggembangan model tersebut telah digeneralisasi penggunaannya pada lahan irigasi air tanah yang memanfaatkan potensi air tanah dalam (akufer terkekang) di wilayah daratan yang tidak memiliki pantai (air tanah tidak berpotensi intrusi air laut) ataupun bukan daerah berkapur (air tanah tidak berpotensi memiliki kekerasan karbonat tinggi) (Siswoyo et al., 2020 ) dan lahan pertanian yang memanfaatkan potensi mata air karst sebagai sumber air irigasinya (Siswoyo et al., 2020 a). Studi serupa terhadap air tanah yang digunakan untuk irigasi pada lahan pertanian di daerah yang dekat dengan pantai dan berpotensi terintrusi air laut masih diperlukan.

Tujuan dilakukannya studi ini adalah untuk menilai kelayakan air tanah yang digunakan sebagai air irigasi berdasarkan aspek kualitas air dengan kriteria nilai indeks kualitas air irigasi. Manfaat secara praktis dengan adanya studi ini adalah tersedianya informasi bagi petani di lokasi studi tentang kesesuaian kualitas air tanah yang digunakan untuk mengairi lahan pertanian yang berada pada daerah di dekat pantai dengan kondisi tanah dan tanaman pada lahan tersebut, serta alternatif jenis tanaman pertanian non padi bernilai ekonomi tinggi yang dapat diusahakan di lokasi setempat.

\section{METODE}

\section{Lokasi dan Waktu Pelaksanaan Studi}

Studi ini dilakukan pada lahan irigasi air tanah di daerah oncoran sumur produksi SDTB 063, SDTB 064, dan SDTB 342. Ketiga lokasi daerah oncoran tersebut berada di wilayah Kecamatan Jenu Kabupaten Tuban Provinsi Jawa Timur. Peta lokasi studi ditunjukkan dalam Gambar 1. Studi ini dilakukan pada bulan Agustus 2019 sampai dengan Desember 2019.

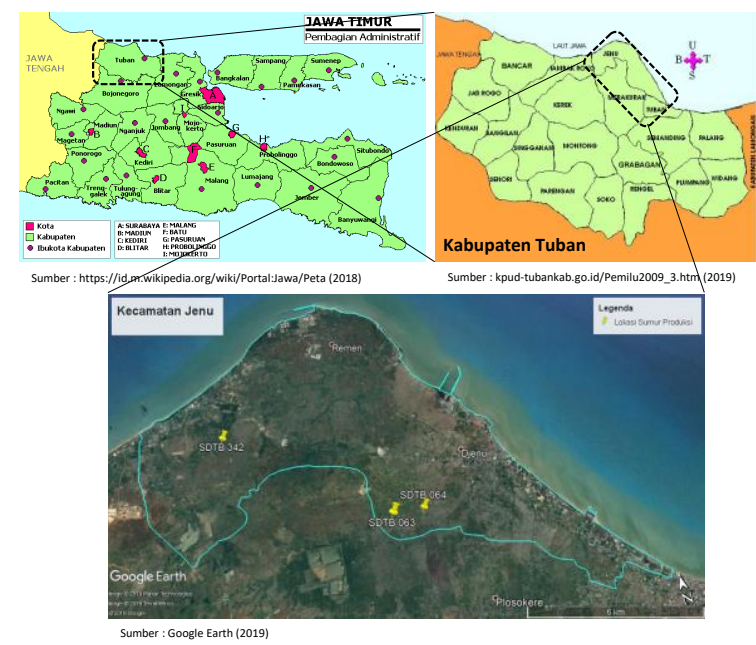

Gambar 1. Peta Lokasi Studi

\section{Alat dan Bahan}

Peralatan yang digunakan dalam studi ini meliputi: GPS untuk menentukan koordinat lokasi studi, termometer model Digital Thermometer TP 3001 untuk mengukur suhu air, konduktimeter model $\mu$ Siemen digital conductivity tester digunakan untuk mengukur daya hantar listrik (DHL) dalam air, botol dari bahan poli etilen untuk wadah contoh air, kotak pendingin yang dilengkapi dengan es gel balok untuk pengawetan contoh air, cetok untuk mengambil contoh tanah, dan ring dari bahan PVC (diameter $5 \mathrm{~cm}$, tinggi $7 \mathrm{~cm}$, tebal 4 $\mathrm{mm}$ ) digunakan sebagai wadah untuk mengambil contoh tanah. Bahan yang digunakan untuk studi ini adalah contoh air tanah yang diambil dari 3 sumur produksi (SDTB 063, SDTB 064, dan SDTB 342) dan contoh tanah dari lahan irigasi air tanah sumur-sumur produksi tersebut.

\section{Metode Pengumpulan Data}

Parameter-parameter kualitas air tanah yang diamati dalam studi ini meliputi suhu air, DHL dalam air, dan kandungan kation-kation maupun anion-anion terlarut dalam air tanah $\left(\mathrm{Na}^{+}, \mathrm{Ca}^{2+}, \mathrm{Mg}^{2+}, \mathrm{HCO}_{3}{ }^{-}\right.$, dan $\mathrm{Cl}^{-}$). Parameter tanah yang diamati adalah permeabilitas tanah. Pengambilan dan pengawetan contoh air tanah secara fisika dilakukan dengan mengikuti ketentuan yang berlaku dalam Standar Nasional Indonesia (Badan Standardisasi Nasional, 2008). Pengambilan contoh tanah dilakukan dengan cara memasukkan ring ke dalam tanah hingga masuk secara sempurna ke dalam tanah, mengeluarkan ring dengan menggunakan pisau, meratakan bagian atas dan bagian bawah contoh tanah, dan menutup kedua bagian tersebut dengan menggunakan plastik. Pengambilan contoh air tanah dari sumur produksi dilakukan pada bulan Agustus 2019, sedangkan pengambilan contoh tanah dari lahan irigasi air tanah dilakukan pada bulan Oktober 2019. Pengujian 
Hari Siswoyo dan Joko Kurniawan, Penilaian Kualitas Air Tanah di Kecamatan Jenu Kabupaten Tuban Berdasarkan Indeks Kualitas Air Irigasi

kandungan kation-kation terlarut dalam contoh air tanah $\left(\mathrm{Na}^{+}, \mathrm{Ca}^{2+}, \mathrm{Mg}^{2+}\right)$ dilaksanakan di Laboratorium Kimia Fakultas MIPA Universitas Negeri Malang dengan Metode Atomic Absorption Spectrophotometry (AAS), yang diselesaikan pada bulan September 2019. Pengujian kandungan anion-anion terlarut dalam contoh air tanah $\left(\mathrm{HCO}_{3}{ }^{-}\right.$dan $\left.\mathrm{Cl}^{-}\right)$dilaksanakan di Laboratorium Tanah dan Air Tanah Fakultas Teknik Universitas Brawijaya, yang juga diselesaikan pada bulan September 2019. Pengujian kandungan anion $\mathrm{HCO}_{3}^{-}$yang terlarut dalam contoh air tanah dilakukan dengan menggunakan metode spektrofotometri, sedangkan pengujian kandungan anion $\mathrm{Cl}^{-}$dilakukan dengan menggunakan metode titrasi volumetri. Pengujian contoh tanah untuk penentuan permeabilitas tanah berdasarkan nilai konduktivitas hidraulik jenuh dilaksanakan di Laboratorium Fisika Tanah Fakultas Pertanian Universitas Brawijaya, yang diselesaikan pada bulan November 2019.

\section{Metode Analisis}

Penilaian kualitas air tanah dengan menggunakan model IQWI (Meireles et al., 2010), dilakukan berdasarkan nilai IWQI yang dihitung berdasarkan persamaan:

$\mathrm{IWQI}=\sum_{\mathrm{i}=1}^{\mathrm{n}} \mathrm{q}_{\mathrm{i}} \times \mathrm{w}_{\mathrm{i}} \ldots \ldots \ldots$ (1)

Keterangan:

IWQI = indeks kualitas air irigasi (0-100)

$\mathrm{q}_{\mathrm{i}}=$ nilai kualitas air parameter ke-i (0-100), merupakan fungsi dari konsentrasi atau nilai pengukuran.

$\mathrm{w}_{\mathrm{i}}=$ faktor pembobot dari parameter ke-i, merupakan fungsi tingkat pengaruh relatif dari nilai kualitas air.

Prosedur perhitungan nilai IWQI telah dideskripsikan pada bagian publikasi sebelumnya (Siswoyo et al., 2020 ${ }^{\mathrm{b}}$; Siswoyo et al., 2020 ). Berdasarkan nilai IWQI dapat ditentukan batasan penggunaan air untuk irigasi dan kesesuaian kualitas air dengan tanah dan tanaman (Meireles et al., 2010), seperti ditunjukkan dalam Tabel 1.

Tabel 1. Karakteristik indeks kualitas air irigasi

\begin{tabular}{|c|c|c|}
\hline \multirow[t]{2}{*}{ IWQI } & \multicolumn{2}{|c|}{ Rekomendasi } \\
\hline & Tanah & Tanaman \\
\hline $\begin{array}{c}85-100 \\
\text { (Tidak ada batasan penggunaan } \\
\text { air) }\end{array}$ & $\begin{array}{l}\text { Tanah dengan kemungkinan yang rendah } \\
\text { terjadi permasalahan sodisitas dan } \\
\text { salinitas }\end{array}$ & $\begin{array}{l}\text { Tidak mengandung resiko toksisitas bagi } \\
\text { sebagian besar tanaman }\end{array}$ \\
\hline $\begin{array}{c}\text { 70-85 } \\
\text { (Batasan penggunaan air rendah) }\end{array}$ & $\begin{array}{l}\text { Tanah yang memiliki tekstur ringan atau } \\
\text { tanah yang memiliki permeabilitas sedang }\end{array}$ & $\begin{array}{l}\text { Tidak untuk diberikan bagi tanaman-tanaman } \\
\text { yang sensitif terhadap garam }\end{array}$ \\
\hline $\begin{array}{c}55-70 \\
\text { (Batasan penggunaan air sedang) }\end{array}$ & $\begin{array}{l}\text { Tanah yang memiliki kelas permeabilitas } \\
\text { sedang sampai dengan tinggi, dan } \\
\text { ditunjang dengan tindakan pencucian } \\
\text { garam }\end{array}$ & $\begin{array}{l}\text { Tanaman dengan toleransi sedang terhadap } \\
\text { garam dapat tumbuh. }\end{array}$ \\
\hline $\begin{array}{c}40-55 \\
\text { (Batasan penggunaan air tinggi) }\end{array}$ & $\begin{array}{l}\text { Tanah yang memiliki kelas permeabilitas } \\
\text { tinggi tanpa lapisan yang dipadatkan }\end{array}$ & $\begin{array}{l}\text { Tanaman yang memiliki tingkat toleransi } \\
\text { sedang sampai dengan tinggi terhadap garam, } \\
\text { yang disertai upaya pengendalian salinitas }\end{array}$ \\
\hline $\begin{array}{c}0-40 \\
\text { (Batasan penggunaan air parah) }\end{array}$ & $\begin{array}{l}\text { Harus dihindari penggunaannya untuk } \\
\text { irigasi dalam kondisi normal, guna } \\
\text { mencegah terjadinya penumpukan garam }\end{array}$ & $\begin{array}{l}\text { Tanaman dengan toleransi yang tinggi terhadap } \\
\text { garam }\end{array}$ \\
\hline
\end{tabular}

Sumber: Meireles et al. (2010)

Kategori tanaman yang direkomendasikan berdasarkan batasan penggunaan air disesuaikan dengan kriteria toleransi relatif tanaman-tanaman pertanian terhadap garam (Ayers \& Westcot, 1994). Jenis tanaman berdasarkan kriteria toleransi relatifnya terhadap garam disesuaikan dengan jenis tanaman pertanian non padi yang termasuk dalam kategori tanaman bernilai ekonomi tinggi (Haryono et al., 2009). Jenis tanaman-tanaman yang telah disesuaikan dengan kriteria tanaman pertanian non padi yang memiliki nilai ekonomi tinggi disesuaikan dengan jenis tanaman yang cara bercocok tanamnya telah dikuasai oleh para petani di wilayah Kabupaten Tuban (Badan Pusat Statistik Kabupaten Tuban, 2019a $2019^{\mathrm{b}}$ ).

\section{HASIL DAN PEMBAHASAN}

Studi ini diawali dengan survei pendahuluan untuk menentukan lokasi pengambilan contoh. Berdasarkan lokasi yang ditentukan, dilakukan pengambilan contoh air tanah dari sumur produksi, pengambilan contoh tanah dari lahan pertanian, dan wawancara dengan petani. Hasil investigasi di lapangan dan hasil pengujian di laboratorium terhadap contoh air tanah maupun contoh tanah dideskripsikan di dalam Tabel 2. Hasil penilaian terhadap kualitas air tanah untuk irigasi menggunakan model IWQI ditunjukkan dalam Tabel 3. 
Hari Siswoyo dan Joko Kurniawan, Penilaian Kualitas Air Tanah di Kecamatan Jenu Kabupaten Tuban Berdasarkan Indeks Kualitas Air Irigasi

Tabel 2. Hasil investigasi di lapangan dan hasil pengujian laboratorium

\begin{tabular}{|c|c|c|c|}
\hline \multirow{2}{*}{ Deskripsi } & \multicolumn{3}{|c|}{ Sumur Produksi } \\
\hline & SDTB 063 & SDTB 064 & SDTB 342 \\
\hline a'Desa & Desa Suwalan & Desa Suwalan & Desa Temaji \\
\hline \multicolumn{4}{|l|}{${ }^{\mathrm{a}}$ Rumah pompa } \\
\hline \multirow[t]{2}{*}{${ }^{\mathrm{a}}$ Observasi GPS } & $6^{\circ} 50^{\prime} 31^{\prime \prime} \mathrm{LS}$ & 650’34” LS & $6^{\circ} 48^{\prime} 7^{\prime \prime} \mathrm{LS}$ \\
\hline & $111^{\circ} 57^{\prime} 59^{\prime \prime} \mathrm{BT}$ & $111^{\circ} 58^{\prime} 36^{\prime \prime} \mathrm{BT}$ & $111^{\circ} 55^{\prime} 7^{\prime \prime} \mathrm{BT}$ \\
\hline \multicolumn{4}{|l|}{ Contoh air tanah } \\
\hline 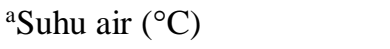 & 29,80 & 29,80 & 29,40 \\
\hline${ }^{\mathrm{a} D H L}(\mu \mathrm{S} / \mathrm{cm})$ & 1102,00 & 715,00 & 1068,00 \\
\hline${ }^{\mathrm{b}}$ Kandungan $\mathrm{Na}^{+}(\mathrm{mg} / \mathrm{l})$ & 8,97 & 8,39 & 2,28 \\
\hline${ }^{\mathrm{b}} \mathrm{Kandungan} \mathrm{Mg}^{2+}(\mathrm{mg} / \mathrm{l})$ & 66,52 & 49,28 & 38,33 \\
\hline${ }^{\mathrm{b}} \mathrm{Kandungan} \mathrm{Ca}^{2+}(\mathrm{mg} / \mathrm{l})$ & 69,47 & 75,97 & 71,15 \\
\hline${ }^{\mathrm{c}}$ Kandungan $\mathrm{HCO}_{3}{ }^{-}(\mathrm{mg} / \mathrm{l})$ & 427,00 & 390,00 & 366,00 \\
\hline${ }^{\mathrm{c}}$ Kandungan $\mathrm{Cl}^{-}(\mathrm{mg} / \mathrm{l})$ & 18,61 & 5,14 & 14,54 \\
\hline
\end{tabular}

Contoh tanah

${ }^{\mathrm{d}}$ Konduktivitas hidraulik

${ }^{\mathrm{a}}$ Lahan pertanian

${ }^{\text {aPola tanam }}$

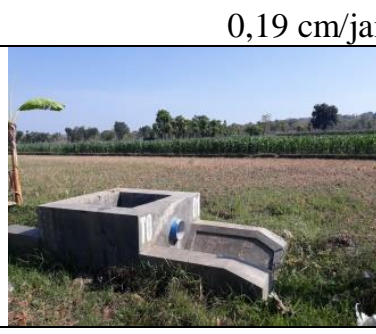

Padi-Jagung-Kacang Tanah

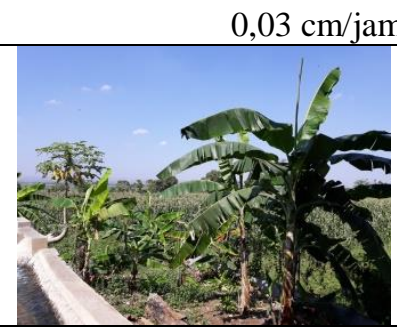

Padi-Padi-Jagung

$0,04 \mathrm{~cm} / \mathrm{jam}$

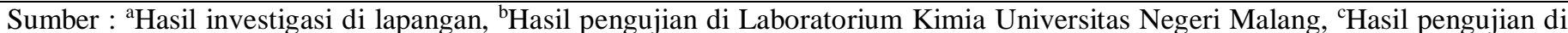
Laboratorium Tanah dan Air Tanah Universitas Brawijaya, ${ }^{\mathrm{d}}$ Hasil pengujian di Laboratorium Fisika Tanah Universitas Brawijaya.

Tabel 3. Penilaian kualitas air tanah berdasarkan nilai IWQI di lokasi penelitian

\begin{tabular}{|c|c|c|}
\hline \multirow[t]{2}{*}{ Penilaian Kualitas Air } & \multicolumn{2}{|r|}{ Sumur Produksi } \\
\hline & SDTB 063 & SDTB 342 \\
\hline Nilai IWQI & 67,89 & 70,65 \\
\hline Batasan penggunaan air & $\begin{array}{c}\text { Sedang } \\
\text { (Moderate Restriction) }\end{array}$ & $\begin{array}{c}\text { Rendah } \\
\text { (Low Restriction) }\end{array}$ \\
\hline Kesesuaian dengan tanah & $\begin{array}{l}\text { Dapat diberikan pada lahan pertanian } \\
\text { dengan kondisi tanah yang memiliki } \\
\text { kelas permeabilitas sedang sampai } \\
\text { dengan tinggi, dan ditunjang dengan } \\
\text { tindakan pencucian garam. }\end{array}$ & $\begin{array}{l}\text { Dapat diberikan pada lahan pertanian dengan kondisi } \\
\text { tanah bertekstur ringan atau memiliki kelas } \\
\text { permeabilitas sedang. }\end{array}$ \\
\hline Kesesuaian dengan tanaman & $\begin{array}{l}\text { Dapat diberikan bagi tanaman yang } \\
\text { memiliki toleransi sedang terhadap } \\
\text { garam }\end{array}$ & $\begin{array}{l}\text { Tidak untuk diberikan bagi tanaman-tanaman yang } \\
\text { sensitif terhadap garam. }\end{array}$ \\
\hline
\end{tabular}

Sumber: Hasil Analisis

Berdasarkan nilai IWQI yang diperoleh menurut hasil perhitungan model IWQI dapat ditentukan kualitas air tanah berdasarkan batasan penggunaan air tersebut untuk irigasi. Air tanah dari sumur produksi SDTB 064 dan SDTB 342 miliki batasan penggunaan air rendah, sedangkan yang berasal dari sumur SDTB 603 memiliki batasan penggunaan air sedang. Air tanah dengan batasan penggunaan air rendah direkomendasikan dapat dipakai sebagai sumber air irigasi untuk tanah dengan tekstur yang ringan atau memiliki permeabilitas sedang, sedangkan air tanah dengan batasan penggunaan air sedang direkomendasikan untuk dapat dipakai pada tanah dengan tingkat permeabilitas sedang sampai dengan tinggi. 
Tanah pada lahan irigasi air tanah sumur produksi SDTB 063 memiliki nilai konduktivitas hidraulik 0,19 $\mathrm{cm} / \mathrm{jam}$, tanah pada lahan irigasi sumur produksi SDTB 064 memiliki konduktivitas hidraulik 0,03 cm/jam, sedangkan pada lahan irigasi SDTB 342 sebesar 0,04 $\mathrm{cm} / \mathrm{jam}$. Kondisi tanah pada ketiga lokasi studi memiliki kelas permeabilitas lambat. Tanah dengan kelas permebilitas lambat adalah tanah yang memiliki tekstur halus atau tanah yang memiliki kandungan setidaknya $37,5 \%$ liat atau memiliki tekstur liat, liat berdebu, atau liat berpasir (Hanafiah, 2012). Tingkat permeabilitas untuk tanah di lokasi studi berdasarkan hasil analisis terhadap contoh tanah yang diambil dari lapang tidak bersesuaian dengan rekomendasi berdasarkan hasil analisis model IWQI. Untuk itu perlu dilakukan upaya pencucian garam pada tiap lahan irigasi air tanah.

Nilai permeabilitas tanah berbanding lurus dengan nilai laju infiltrasi (Askoni \& Sarminah, 2018), sehingga upaya untuk meningkatkan permeabilitas tanah dapat ditempuh melalui upaya peningkatan laju infiltrasi. Peningkatan laju infiltrasi dan permeabilitas tanah dapat dilakukan melalui upaya revegetasi, dimana tanaman yang tumbuh akan dapat memberikan kontribusi bahan organik terhadap tanah sehingga akan dapat memperbaiki kondisi tekstur maupun struktur tanah (Tambunan et al., 2018). Sistem perakaran pada vegetasi dan seresah yang dihasilkannya akan memberikan dampak terhadap meningkatknya permeabilitas tanah sehingga laju infiltrasi juga akan meningkat (Asdak, 2002). Peningkatan laju infiltrasi sekaligus kesuburan lahan pertanian juga dapat dilakukan dengan menggunakan Metode Biosoildam (Widiasmadi, 2019).

Air tanah dengan batasan penggunaan air rendah direkomendasikan tidak untuk diberikan terhadap jenis tanaman yang berada dalam kategori sensitif terhadap garam, sedangkan air tanah yang memiliki batasan penggunaan air sedang direkomendasikan untuk diberikan sebagai air irigasi setidaknya pada tanaman dengan toleransi sedang terhadap garam. Penentuan jenis tanaman pertanian untuk direkomendasikan dapat dibudidayakan pada lahan pertanian berdasarkan kualitas air yang digunakan untuk irigasi di lokasi studi, dilakukan dengan acuan bahwa untuk air irigasi dengan batasan penggunaan rendah tidak diberikan pada tanaman yang sensitif terhadap garam, sedangkan untuk air irigasi dengan batasan penggunaan sedang bisa diperuntukkan bagi tanaman yang memiliki tingkat toleransi sedang terhadap garam. Air irigasi tidak diberikan untuk tanaman yang sensitif terhadap garam berarti bahwa air irigasi tersebut dapat diberikan untuk tanaman yang cukup sensitif, cukup toleran, dan toleran terhadap garam. Air irigasi yang dapat diperuntukkan bagi tanaman yang memiliki tingkat toleransi sedang terhadap garam dapat diartikan bahwa air tersebut dapat diberikan untuk tanaman yang cukup toleran dan toleran terhadap garam.
Kategori tanaman cukup sensitif terhadap garam (Ayers \& Westcot, 1994) yang dapat disesuaikan dengan kriteria tanaman pertanian non padi bernilai ekonomi tinggi (Haryono et al., 2009) dan cara bercocok tanamnya telah dikuasai oleh petani di Kecamatan Jenu Kabupaten Tuban (Badan Pusat Statistik Kabupaten Tuban, 2019a $2019^{\mathrm{b}}$ ) adalah jagung (Zea mays), kacang tanah (Arachis hypogaea), ubi jalar (Ipomoea batatas), tomat (Lycopersicon lycopersicum), terong (Solanum melongena), mentimun (Cucumis sativus), bayam (Spinacia oleracea), tebu (Saccharum officinarum), melon (Cucumis melo), semangka (Citrullus lanatus), dan anggur (Vitis vinifera). Untuk kategori tanaman cukup toleran terhadap garam adalah pepaya (Carica papaya). Untuk kategori tanaman yang toleran terhadap garam tidak ada yang dapat disesuaikan.

Rekomendasi untuk alternatif jenis tanaman pertanian non padi yang memiliki nilai ekonomi tinggi untuk dapat ditanam pada lahan pertanian sumur produksi SDTB 064 dan SDTB 342 antara lain jagung (Zea mays), kacang tanah (Arachis hypogaea), ubi jalar (Ipomoea batatas), tomat (Lycopersicon lycopersicum), terong (Solanum melongena), mentimun (Cucumis sativus), bayam (Spinacia oleracea), tebu (Saccharum officinarum), melon (Cucumis melo), semangka (Citrullus lanatus), anggur (Vitis vinifera), dan pepaya (Carica papaya). Sementara itu, pada lahan pertanian yang memanfaatkan air irigasi dari sumur produksi SDTB 063 dapat ditanami pepaya (Carica papaya) atau dapat dicoba untuk diusahakan tanaman kedelai (Glycine max) yang berada dalam kategori tanaman cukup toleran terhadap garam.

Lahan irigasi air tanah dari sumur produksi SDTB 064 dan SDTB 342, tanaman pertanian non padi yang telah dibudidayakan (jagung) sudah sesuai dengan kualitas air irigasi yang diberikannya. Pada kedua lahan tersebut juga dapat diusahakan tanaman pertanian dengan alternatif seperti dinyatakan di atas. Untuk lahan irigasi air tanah dari sumur produksi SDTB 063 apabila diusahakan tanaman seperti pada kondisi eksisting maka perlu dilakukan pengolahan tanah yang intensif untuk meningkatkan permeabilitas tanah atau diusahakan tanaman seperti dinyatakan di atas.

\section{SIMPULAN}

Air tanah di lokasi studi memiliki batasan penggunaan air rendah (ditemukan pada sumur produksi SDTB 064 dan SDTB 342) dan batasan penggunaan air sedang (ditemukan pada sumur produksi SDTB 063) sebagai sumber air irigasi. Kualitas air tanah dengan batasan penggunaan air rendah direkomendasikan untuk diberikan pada tanah dengan permeabilitas sedang dengan anjuran dilakukan pencucian garam dan dapat diberikan pada tanaman yang cukup sensitif, cukup toleran, dan toleran terhadap garam. Kualitas air tanah dengan batasan penggunaan air sedang direkomendasikan untuk diberikan pada tanah yang 
memiliki kelas permeabilitas sedang sampai dengan tinggi dengan anjuran dilakukan pencucian garam dan dapat diberikan untuk tanaman yang cukup toleran dan toleran terhadap garam. Petani di lokasi studi dapat mengusahakan beberapa alternatif tanaman pertanian non padi bernilai ekonomi tinggi seperti dinyatakan dalam hasil studi ini dengan tetap melakukan penyesuaian terhadap kondisi lahan pertanian dan kondisi iklim.

\section{DAFTAR PUSTAKA}

Abdulhady, Y., Zaghlool, E., \& Gedamy, Y. (2018). Assesment of the Groundwater Quality of the Quaternery Aquifer in Reclaimedareas at the Northwestern El-Minya Governorate - Egypt, using the Water Quality Index. International Journal of Recent Scientific Research, 9(1), 23033-23047.

Al-Mussawi, W. H. (2014). Assesment of Groundwater Quality in UMM ER Radhuma Aquifer (Iraqi Western Desert) by Integration between Irrigation Water Quality Index and GIS. Journal of Babylon University/ Engineering Sciences, 22(1), 201-217.

Asdak, C. (2002). Hidrologi dan Pengelolaan Daerah Aliran Sungai. Cetakan Kedua. Yogyakarta: Gadjah Mada University Press.

Askoni \& Sarminah, S. (2018). Laju Infiltrasi dan Permeabilitas pada Beberapa Tutupan Lahan di Hutan Pendidikan Fakultas Kehutanan Universitas Mulawarman Samarinda. Ulin-J. Hut. Trop., 2(1): 6-15

Ayers, R. S. \& Westcot, D. W. (1994). Water quality for agriculture, FAO Irrigation and Drainage Paper 29 Rev.1. Rome: Food and Agriculture Organization of the United Nations.

Badan Pusat Statistik Kabupaten Tuban. (2019)a. Kabupaten Tuban Dalam Angka 2019. Tuban: Badan Pusat Statistik Kabupaten Tuban.

Badan Pusat Statistik Kabupaten Tuban. (2019) Kecamatan Jenu Dalam Angka 2019. Tuban: Badan Pusat Statistik Kabupaten Tuban.

Badan Standardisasi Nasional. (2008). Standar Nasional Indonesia (SNI) 6989.58:2008 tentang Air dan Air Limbah-Bagian 58: Metoda Pengambilan Contoh Air Tanah. Jakarta: Badan Standardisasi Nasional.

Hanafiah, K. A. (2012). Dasar-dasar Ilmu Tanah. Cetakan ke-5. Jakarta: PT. Raja Grafindo Persada.

Haryono, E., Santoso, D., Sumarni, H., \& Indrakusuma, H. I. (2009). Kriteria Pengembangan dan Pengelolaan Irigasi Air Tanah. Jakarta: Direktorat Irigasi, Direktorat Jenderal Sumber Daya Air, Kementerian Pekerjaan Umum.

Khalaf, R. M. \& Hassan, W. Q. (2013). Evaluation of Irrigation Water Quality Index (IWQI) for AlDammam Confined Aquifer in the West and Southwest of Karbala City, Iraq. International Journal of Civil Engineering, 2(3), 21-34.
Meireles, A. C. M., de Andrade, E. M., Chaves, L. C. G., Frischkorn, H., \& Crisostomo, L. A. (2010). A New Proposal of the Classification of Irrigation Water. Revista Ciência Agronômica, 41(3), 349357.

Omran, E. S. E., Ghallab, A., Selmy, S., \& Gad, A. A. (2014). Evaluation and mapping of water wells suitability for irrigation using GIS in Darb ElArbaein, South Western Desert, Egypt. International Journal of Water Resources and Arid Environments, 3(1), 63-76.

Siswoyo, H., Agung, I G. A. M. S., Swantara, I M. D., \& Sumiyati. (2016). Determination of Groundwater Quality Index for irrigation and its Suitability for Agricultural Crops in Jombang Regency, East Java, Indonesia. International Journal of Agronomy and Agricultural Research, 9(5), 6267.

Siswoyo, H., Bisri, M., Taufiq, M \& Pranantya, V. $(2020)^{a}$. Kesesuaian Jenis Tanaman Pertanian dengan Kualitas Air Irigasi dari Beberapa Mata Air Karst di Kabupaten Tuban. Rekayasa, 13 (3), 246-253.

Siswoyo, H., Juwono, P. T., \& Taufiq, M. (2018). Potensi Bahaya Salinitas dan Bahaya Alkalinitas Sumber Daya Air Tanah untuk Irigasi di Kabupaten Mojokerto. Prosiding Seminar Nasional Inovasi Teknologi Terapan Politeknik Negeri Balikpapan 2018 (pp. 109-115). Politeknik Negeri Balikpapan. Balikpapan.

Siswoyo, H., Juwono, P. T., \& Taufiq, M. (2020) . Model Indeks Kualitas Air Tanah sebagai Dasar Penentuan Alternatif Jenis Tanaman Pertanian pada Lahan Irigasi Air Tanah di Kabupaten Mojokerto. Jurnal Wilayah dan Lingkungan, 8(1), $1-14$.

Tambunan, L., Husain, J., \& Supit, J. M. J. (2018). Infiltrasi dan Permeabilitas pada Tanah Reklamasi Tambang Emas. Eugenia, 24(1): 15-26.

Tika, M. P. (1990). Pengelolaan Irigasi Sumur Pompa. Jakarta: Yayasan Badan Penerbit Pekerjaan Umum.

Undang-undang Republik Indonesia Nomor 17 Tahun 2019 tentang Sumber Daya Air.

Widiasmadi, N. (2019). Peningkatan Laju Infiltrasi dan Kesuburan Lahan dengan Metode Biosoildam pada Lapisan Tanah Keras dan Tandus. Prosiding SNST ke-10 Tahun 2019 (pp. 43-48). Fakultas Teknik Universitas Wahid Hasyim. Semarang. 